\title{
THE FESTIVAL DEDICATED TO THE ANNIVERSARY OF THE VISION OF AGIA PELAGIA AND OTHER RITUALS
}

\author{
EVY JOHANNE HÅLAND
}

The local festival dedicated to the Anniversary of the Vision of Agia (Saint) Pelagia or Osia (Venerable, Blessed, Saint) ${ }^{1}$ Pelagia is celebrated on the Greek island of Tinos and is dedicated to one of the most recent Orthodox saints, Saint Pelagia, a nun that was sanctified in 1971. After the great Greek War of Liberation (1821) broke out, the pious nun Pelagia had several mystical visions that lead to the discovery of the miraculous icon of the Annunciation.

Keywords: Greece, history, legends, memory, myth, religious festivals
Lokalni festival, namenjen obletnici Videnja agie (svetnice) ali osie (častite, blažene, svetnice) Pelagije, praznujejo na grškem otoku Tinosu in je posvečen eni najnovejsih pravoslavnih svetnic, leta 1971 za sveto razglašeno redovnico Agio Pelagijo. Po izbruhu grške osvobodilne vojne (1821) je imela pobožna redovnica Pelagija več mističnih videnj, ki so vodila v odkritje čudežne ikone Oznanjenja.

Ključne besede: Grčija, zgodovina, legende, spomin, mit, verski prazniki

In 1823, after several mystical visions by a pious nun named Pelagia (Figure 1), the miraculous holy icon of the Annunciation (Grk. Euangelismos) of the Panagia (Megalochari, i.e. Blessed Virgin) was found. According to tradition, the nun Pelagia had repeated visions of the Mother of the God, Panagia, who ordered her to inform the elders to start excavations in order to find her icon, buried many years earlier in an uncultivated field, and to build her "house" (i.e., her church) at that place. On 30 January 1823, the icon, said to be the work of Agios (Saint) Luke, was unearthed in the field where it had remained for about 850 years, since a church built on the ruins of the pagan temple of Dionysos was destroyed

1 The transliteration of Greek follows the rules of the Nordic Library, Athens, but when quoting from a published text another style may be used because there are several different ways of transliterating Greek texts. Strictly speaking, Pelagia is not an Agia 'saint' but Osia 'venerable, blessed'. Her official name is Pelagias os. (i.e., Osia) en Tènos, thus distinguishing her from another Saint Pelagia within the Orthodox church from whom she took her name, and who is celebrated on 4 May. One of my male informants from Tinos, one of the chorus members at Annunciation Church, stresses that Pelagia of Tinos is not a saint like Saint Nicholas, for example, because miracles are not attributed to her. According to one of my other informants, a young female scholar from Thessaloniki, there are two kinds of saints, or rather two levels_-Agia (f.) / Agios (m.) and Osia (f.) / Osios (m.), for ceremonial reasons. She further explains that Osia/Osios is the designation for a person that has participated in something of religious importance, but miracles are never attributed to this person. The difference is also seen in the liturgy because the liturgy performed for an Osia/Osios is much shorter than the liturgy performed for an AgialAgios. They both emphasize that Pelagia is an Osia, which means that she is "further down" within the hierarchical structure of saints. This might also be the reason that she is not found on all lists of saints in Greece. The nuns I have been talking with in the convent where she lived, however, regard her as an Agia, as do also most ordinary people on the island, particularly the women. Furthermore, some of her icons refer to her as an Agia (i.e., E Agia Pelagia É en Tènō), as I also do in this study. 


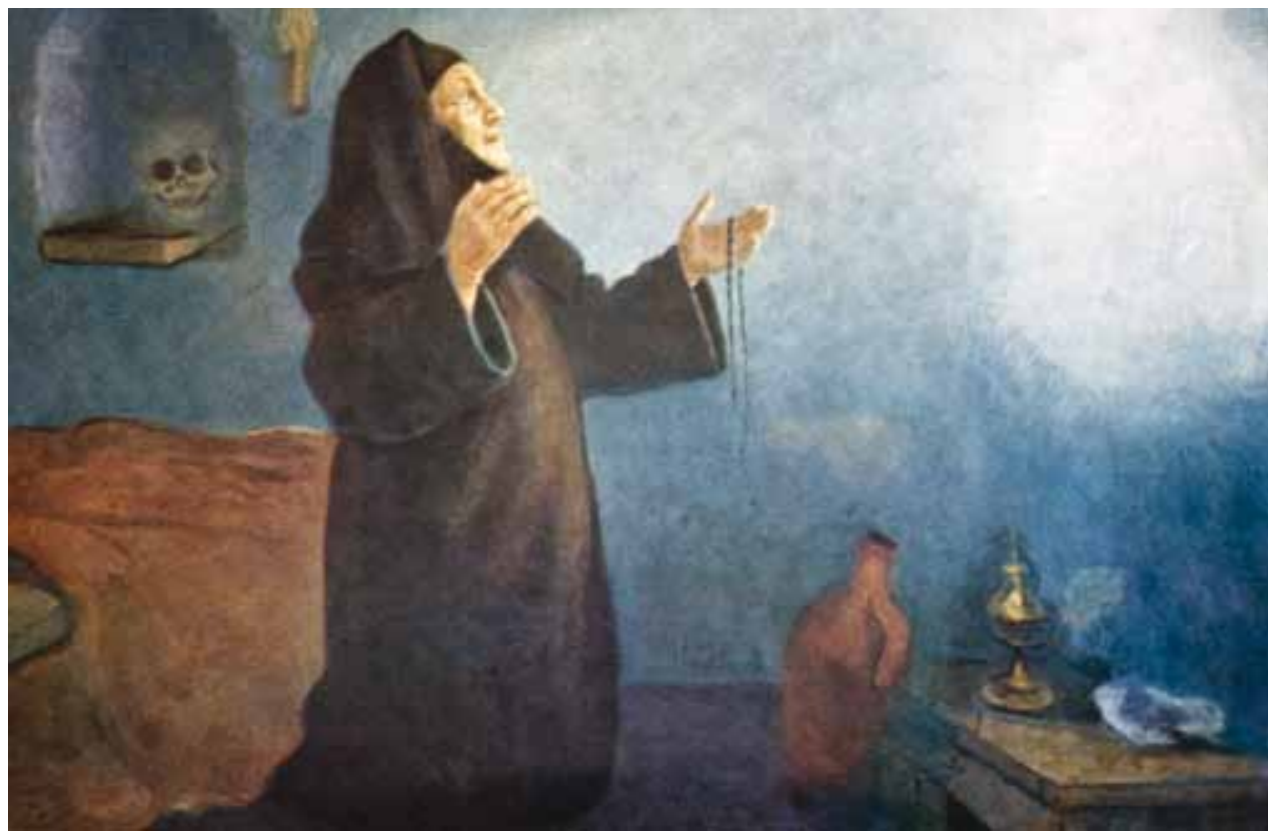

Figure 1. Painting illustrating Agia Pelagia receiving the vision on the Aegean island of Tinos. (Photo by E.J. Håland)

and burned down by the Saracens in the tenth century AD. Two years before the icon was found, the great Greek War of Liberation (1821) broke out. The discovery of the icon, the construction of the Church of Panagia Evangelistria, the enormous crowds of pilgrims, and all the miracles worked by the icon, contributed to the island being declared sacred by a government decree in 1971. Pelagia was also sanctified. In addition to the thousands of pilgrims that come to Tinos on their own, several pilgrimages are organized by representatives of the Orthodox Church, such as in Athens or Larissa, particularly in connection with the most important festival on 15 August.

Below the main church on Tinos are several cave-shaped chapels, one of which is dedicated to the Life-Giving Spring. Rituals connected with water are important here, as in all Greek churches. The legend continues, stating that the first excavations on Tinos brought to light the ruins of the foundations of the Byzantine church, first and foremost a deep but dry well. Some months later, in 1823, the cornerstone of the church dedicated to the Life-Giving Spring was laid. Later, the icon was found approximately two meters from the well. After the icon was found, it was decided to build a large church above the church dedicated to the Life-Giving Spring. Thus, the chapel or church dedicated to the Life-Giving Spring, which is designed like a cave, is located below Annunciation Church.

As already mentioned, the mouth of a well was found during the excavations made during the search for the icon, but the well was completely dry and useless. On the day the church cornerstone was laid, however, the formerly dry well was filled to the brim with water. 
The spring is seen as a miracle, and according to tradition it is one of the most important miracles of the Panagia of Tinos. Since the discovery of water in this well, pilgrims have regarded it as sacred water. Accordingly, small or large bottles of this precious water are taken home by pilgrims from all over the world, and they keep it at home as a talisman. They also take some soil from the hole where the miraculous icon was found. Everyone on Tinos knows the legend and the most famous miracles worked by the holy icon by heart, and they recount them to newcomers. The pilgrims, however, are also informed by reading a printed pamphlet distributed by the church. ${ }^{2}$

The pamphlet, written by E. A. Foskolos and first published in 1968, is titled Description of the Finding of the Miraculous Holy Icon of the Annunciation on Tinos in the year 1823: Goals and Activities of the Holy Institution, The Panhellenic Shrine of Our Lady of the Annunciation of Tinos: History, Miracles, Activities. ${ }^{3}$ In the shorter English version of the pamphlet from 2004, in section 2, "The Holy Virgin's Message to the People in Visions to a Pious Nun" we can read:

During the year 1822, a Nun named Pelaghia was visited by vision of the Holy Virgin. In the visions, she was ordered by the Blessed Mother to go to the Town of Tenos and inform the elders that it was Her wish that excavations be made to find Her Holy Icon. The holy Virgin gave Pelaghia a description of the exact location in an uncultivated field where they would find the Icon which lay buried since the destruction of the Ancient Church. After retrieving it from the ground, a Church was to be built to honor the Holy Virgin and to house Her Icon.

Pelaghia at first hesitated to speak of the visions, and assumed that people would not believe her. However, she was overwhelmed with the knowledge that she, a simple but religious mortal, had been chosen by Divine Grace to make this wondrous announcement to the people of Tenos.

Pelaghia went to Tenos and informed the Bishop of Tenos about her Divine Visions. The Bishop, a wise, prudent and pious man, who was fully aware of the virtue and holiness of Pelaghia, believed the words of the Nun. The Bishop was reminded of the narration of an older resident of the town who, a few years prior to this joyous news had also expressed the Holy Virgin's desire that her Holy Icon be found. The Bishop knew that throughout Christian History, God had revealed his Divine Will through visions to pious persons. Deeply moved, the Bishop gave his blessing to the Chosen Nun and ordered the ringing of all church bells to rally the people of Tenos. With faith in his heart, the Bishop informed the populace about the visions of Pelaghia and

2 Cf. Foskolos (1996). Karita (no date) gives a substantially longer description in the book about the life of Pelagia.

3 It is republished annually in Greek, and since 1991 shorter versions have also been translated into English, French, and German. The latest English translation is from 2009. 
expressed his belief that the Blessed Virgin's wish was that the Sacred Icon

be found. (cf. Foskolos, 2004: 6-7, translated by Theodora D. Silvestros)

The next section (part 3) outlines the preliminary excavations that brought to light the ruins of the foundations of the ancient church and the dry well, but no icon. Accordingly, people's enthusiasm diminished, and the excavations stopped. Following a cholera epidemic believed to be the punishment from the Virgin for stopping the excavations, these were resumed, and finally the icon was unearthed, as outlined in section 4: "Discovery of the Holy Icon" (Foskolos, 2004: 7-9).

During the festival calendar on Tinos, the greatest shrine of Greek Orthodoxy, the miraculous icon has its own ritual year, and the annual festive cycle on Tinos starts on 30 January with the festival dedicated to the finding of the icon, when the event is ritually reenacted. The next festival is dedicated to the Day of the Annunciation of the Virgin Mary. This day has both a religious and a national ideological significance because 25 March is celebrated as Independence Day. 23 July is dedicated to the Vision of Saint Pelagia. The most important festival, the Dormition of the Panagia, is celebrated on 15 August, along with Armed Forces Day.

Official processions carrying the icon in their midst are important parts of the festivals. Popular customs also relate to the importance of fetching holy water and soil as well as other symbols with a long tradition in Greek religions. ${ }^{4}$

\section{JULY: ANNIVERSARY OF THE VISION OF AGIA PELAGIA}

The third important festival on Tinos is dedicated to one of the most recent Orthodox saints, the aforementioned Saint Pelagia. Her Vision is celebrated on 23 July. During this local festival, the ritual connection between the Kekhrovouno Convent, where she lived, and Annunciation Church in the village of Tinos (the main township on the island), is marked by a procession with the miraculous icon (Figure 5).

On the eve of the festival, a liturgy is celebrated in Annunciation Church in the town of Tinos, which is crowded by the islanders, and all those coming home to Tinos for their summer vacations. The icon of Pelagia is decorated with flowers and burning candles, and plays a main role during the liturgy together with the miraculous icon of the Annunciation. Pelagia also has a chapel dedicated to her below the main church. Her icon is placed in front of the stones from earlier sanctuaries that were removed when the miraculous icon was unearthed. Although Annunciation Church wanted to have her bones when they were

4 Since 1983, I have had several periods of fieldwork in the Mediterranean, mainly in Greece and Italy where I have also been conducting research on religious festivals since 1987 (cf. Håland 2007a). Since 1990 I have carried out extensive fieldwork on Tinos, and I witnessed the festival dedicated to the Dormition of the Panagia in 1990, annually in the period from 1993 to 1998 and from 2004 to 2011. I attended the festivals dedicated to Pelagia's Vision in 2005 and 2011, and the following account is mainly based on my fieldwork. 
disinterred three years after her death (as is the general rule within the Orthodox Church), her relics (i.e., her head) are still in the Kekhrovouno Convent, where she had her visions in 1822 (Kardamitsē 1992; Karita no date).

Early the next morning, headed by the church musicians, the miraculous icon is carried in a procession accompanied with the nuns of the convent and islanders to the harbor and carried by taxi to the Kekhrovouno Convent, dedicated to the Dormition of the Panagia, where it remains all day. A mass is celebrated, followed by a lunch "served by the abbess" (according to the program for the festival in 2005) to all the participants, the most significant visitors receiving the most elaborate meals. In 2011, however, the lunch was more meager, officially due to the severe economic crises in Greece. Most people stay at the convent all day, taking the opportunity to visit the cell of Saint Pelagia and see her humble belongings and her ascetic bed. Three years after her death, when she was disinterred, the nuns hid her remains because they did not want them to be buried outside of the convent. Later, her head was found buried in a chapel dedicated to John the Baptist. After lunch several women perform their own liturgy in this church, when a group of women join in singing hymns to Pelagia in front of the iconostasis where they found her skull. Today, her holy head is seen in her church next to her cell, where a liturgy is celebrated in the afternoon. In connection with Pelagia, there is also a death cult in connection with the holy head of Pelagia, which resides in an ornate stand near the main entrance of her church, and through the glass top of the stand the dome of her skull can be seen. To the right of the stand is another stand displaying the visiting icon. In general, pilgrims pay the same devotion to her head as to the miraculous icon of the Annunciation, touching the glass top with similar votive offerings or objects they want to make holy, such as cotton, flowers, green leaves, candles, blessed bread, or cloth. Particularly during the festival, flower buds from the wreath of flowers decorating the stand are considered to be effective amulets after being crossed three times over her head.

Later, during a nine-kilometer procession that takes several hours and consists of the clergy and many faithful, the holy icon is returned to Annunciation Church in the town of Tinos. When departing from the convent church, at the beginning of the procession the icon is carried by the abbess followed by another nun. However, the second carrier shares this duty with a male layperson, who also holds the icon. Later during the procession, the nuns are required to hand the icon over to male priests. It is interesting to note that when handing over the icon soon after leaving the convent, the abbess is very reluctant to do this, and says several times that they want to have the icon remain in the convent longer. Thus, there is a parallel to their unwillingness to hand over the remains of Pelagia and later the skull when it finally was found; that is, a conflict between the female convent and the male church in the town. Arriving in the town of Tinos late at night, the icon and the entire procession are welcomed by fireworks, torches, and the horns of ships and buses. The miraculous icon is returned to the church after sermons and speeches at a podium by the waterfront, thus closing this very picturesque local festival dedicated to the Vision. 


\section{MYSTICAL VISIONS}

The most famous mystical visions in Greece are connected with the Tinos legend. Within Orthodox belief, however, one often learns about someone that sees a saint in his or her sleep demanding that the faithful do various things-for example, to find a buried icon needing to be liberated. Among the Anastenarides (i.e., those who celebrate the Anastenaria festival), for example, dreams and visions are important in connection with finding or making icons: ${ }^{5}$ Among the Anastenarides, there is a particular relationship between the owner of the icon and the icon itself because the owner's family descends from the person that originally found or decided to make the icon, often after a dream in which the saint ordered the dreamer to make the icon. According to the tradition, "someone sees in a dream where to find an icon," or a person "sees in a dream that we have to make an icon." Mystical visions by devout persons and finding buried icons are in fact common features in the Orthodox Church, in both early and modern times, and the legends are often recounted in different ways based on who recounts the actual legend. This is particularly illustrated by my experience from the Acropolis caves in Athens. ${ }^{6}$ The story from Tinos has similarities to the Athenian Acropolis cave dedicated to Our Lady of the Cavern (Grk. Panagia Crysospeeliötissa). This involves an analogous account to the one told on Tinos.

According to the legend behind the cult dedicated to Our Lady of the Golden Cavern in the Acropolis cave in Athens, an icon helped the Athenians save the city against the assault of the Goths: Roxanne, the daughter of a pagan medical doctor, dreamed of the Panagia, who asked her "to set her free; she was imprisoned." In other words, her icon was buried here. After three dreams, she asked the other Christians to go along with her, and she dug and found the icon. Then the Panagia appeared to her in a vision. She promised to help Roxanne liberate Athens. When Alaric came, he wanted to destroy the city. However, a light appeared before them, Alaric saw the Panagia on the city wall, and Alaric departed. According to the legend, he left because he was a Christian and believed in the Panagia. Many of the pagan Athenians interpreted the miracle in their own way, and they thought that the protecting city goddess on the Acropolis, Athena, had appeared on the city wall. The miracle happened in August AD 395 and therefore 15 August is celebrated here in commemoration of the miracle. ${ }^{7}$ The legend was published in an Athenian newspaper in 1989. I have discussed the problematic dating of this newspaper article elsewhere (Håland 2007b). It was shown to me in two of the Athenian Acropolis caves (i.e., churches dating from the fifth or sixth century) where I have conducted fieldwork. The article is framed and glazed, and one of my informants told that

5 Cf. Håland (2007a, chapter 4); see also Håland (2008) for a shorter version and Danforth (1989: 173, cf. $136 \mathrm{ff}$., chapter 1). The following account also draws on these references.

6 See Håland (2007b) for a presentation of the two caves.

7 In this instance another meaning is thus added to the celebration of 15 August, the Dormition of the Panagia. 
he had hung it up. He did not remember exactly when and where the article was published, only that he found (i.e., read) it "some years ago," "the year I was on Tinos during the Panagia" (i.e., 15 August 1989). So, I asked him when and where the article had been published because as a researcher I have to produce documents in support of the information I give, but the discouraging answer he gave was "I don't remember where I found it, only that it is some years old." I determined that he was on Tinos on 15 August 1989.

The article describes the legend behind the cult dedicated to Our Lady of the Cavern in this particular cave. In addition to the aforementioned problematic dating of the article, however, there is also the particular interpretation my Athenian informants put into the article because they recount the legend in their own way: "At the beginning of Christianity there was a miraculous icon in this cave. It was painted by Saint Luke the Evangelist during Mary's lifetime." My informants are eager to stress the relation between the pagans and the Christians and to emphasize the magical power of the icon. ${ }^{8}$ Accordingly, they also say that the icon was brought to the cave when people that did not believe in Christianity were present. The article does not say anything about that, but it tells how the icon helped the Athenians save the city from the Goths (cf. Håland 2007b).

Among all the Orthodox icons, icons depicting the Panagia are most venerated, and the cult has been important since the early Byzantine period, when, according to legend, she revealed herself carrying a sword on the walls of Constantinople and Athens and saved her cities. Since then, the vision of the PanagiaVirgin has accompanied the Greek armed forces in the same way as the ancient goddess Athena. The victory belongs to the Panagia as the commander-in-chief. This is not only recounted in oral literature and by informants, but also illustrated in many popular paintings in Greek culture (Mazarakēs-Ainian 1987).

Athena on the city wall is a common motif in ancient myths about periods of war; for example, when the inhabitants of Troy dreamed that Athena was participating in the fight (Plut. Luc.10.3). Paralleling several stories telling about fighting women—goddesses included — participating in battles, one encounters the armed virgin that protects her territory in the modern and ancient worlds.

Divine intervention by way of a light appearing before the invaders has many ancient parallels; for example the cloud of dust and song from the pilgrims' procession to Eleusis, the omen of Persian disaster in connection with the battle at Salamis (Hdt. 8.65, 8.84), the snowstorm in the war between the democrats and the Thirty Tyrants (Xen. Hell. 2.4,14 f.; Diod. 14.32,2 f.), and the story of the Jewish exodus from Egypt (Clem. Al. Strom. 1.24,163,1-3).

Dreams and the subsequent finding of an icon or divine appearances have traditionally been a common-cause connection in Greece during periods of conflict such as rebellions, the fight for liberation from Turkish rule, and other stories from more recent times when

8 It is also said that today the icon can be found in the church dedicated to the Panagia Crysospèliōtissa, in the neighborhood of Omonia Square. They also call it Eirinē 'peace' or “Sleep” (i.e. 'Death').

9 Cf. Mazarakēs-Ainian (1987, plates 4, 11, 13, 48) and Seremetakis (1991: 237 ff.; modern material: Panagia/ women) with Xen. An. 3.2,11 f. (Artemis). See also Håland (2007a, chapter 6) for further references. 


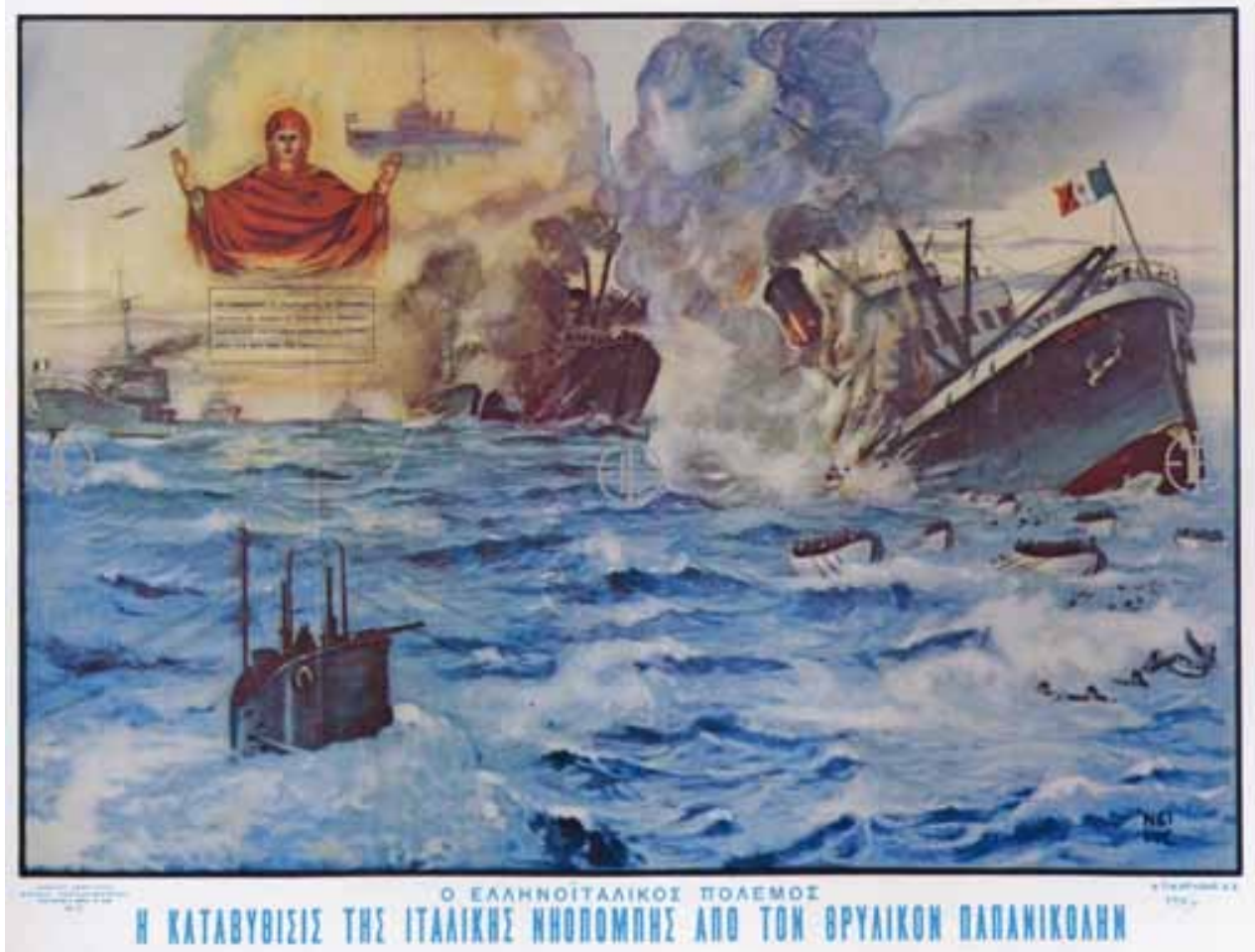

Figure 2. Panagia's active participation in the Graeco-Italian war of 1940, is illustrated in several pictures from the period. Courtesy National Historical museum, Athens.

the nation has been threatened. This mix of politics and religion is particularly manifested in posters announcing the Dormition festival on Tinos today, thus reflecting Byzantine manifestations as well as paintings and newspapers from the war period. It may, for example, be illustrated by a painting of a battleground filled with soldiers during the GrecoItalian war in 1940 and 1941. The Panagia and the child are hovering in the clouds above, accompanied by angels, one of which carries a Greek flag. ${ }^{10}$ According to some, the church on Tinos also dedicated the entire collection of votive offerings to assist the Allies during the Second World War, thus paralleling the Panagia's active participation as illustrated in several pictures from the period (Figure 2). ${ }^{11}$

In the popular summer festival of Agios Charalampos (Saint Charalampos) in the village of Agia Paraskeuē on the island of Lesbos, we also meet the coupling of "Greekness" and Orthodoxy, through the concept that the Greek War of Liberation had divine sanction because, according to the local legend, the saint appeared on Mount Tauros/Taurus (i.e., the mountain of the bull) before the war of liberation broke out. Since this miraculous appearance, the festival has been celebrated annually.

10 Cf. Mazarakēs-Ainian (1987, plate 11; see also plates 4, 13, 48).

11 Cf. Mazarakēs-Ainian (1987). 
This festival is based on the following legend which is told by all villagers to visitors arriving at Agia Paraskeuē: During the period of the Turkish occupation, a farmer from Agia Paraskeuē named Malomytēs lost his ox. While searching for it, he entered the headquarters of a Turkish bandit, who attempted to kill him. However, every time he was about to pull the trigger, his human victim vanished in front of his eyes. The Turk attributed this miracle to Agios Charalampos, who was venerated in the area. He left his cover, and approached the Christian, gave him back his ox, which he had stolen, and told him to light a candle to the saint because he had saved him. Malomytēs, deeply disturbed, returned to his village and told the village elders of the miracle. Carrying the saint's icon, the priest and the elders set off to mountain Tauros. Shortly afterwards the Turks, having seen the lights lit by the Christians, arrived in an angry mood. However, they accepted the explanation they were given, gave permission for a service to be performed, and told the elders to come every year to honor their saint, without fear. ${ }^{12}$ This story recounts the main elements of the legend that I was told by my informants when I visited the village in 1992. The same story was told by the staff at the local council house and by the organizers of the festival. The main factors are also found in the various written versions of the legend. The most extensive is recorded by Christopha D. Chatzēgiannē in a pamphlet from 1969. In vernacular language, and after a paragraph introducing the village with particular focus on the history of the ploughmen's guild founded in 1774, and specifically protected by Saint Charalampos, he describes the legend under the title "The Miracle of the Bull":

East of the village, we find a great end extensive pine-forest, the Tsamliki. ... At the northeastern part of this forest, . . . at the slope of mountain Tauros, in the middle of the pines, above a spring, is a small chapel dedicated to Agios Charalampos. Through the forest one can see the sea and the coast of Asia Minor (i.e., Turkey) on the other side. At the beginning of the nineteenth century, the chapel was more or less demolished. . . No liturgies were celebrated because the Turks were terrorizing people. The place acted as a refuge for a Turkish robber that used to plunder the area. People from the village of Agia Paraskeue didn't carry any weapons. In this place, a miracle occurred that became the starting point for the festival celebrated at Tauros, according to the official tradition.

One day, a farmer (i.e., a ploughman) from Agia Paraskeue named Malomytès lost his ox. While searching for the animal, he entered the place called Tsamliki, the area of Tauros which in those days was untrodden by a Christian foot. The bull, however, was not to be seen. In despair he passed by the spring and came to a clearing, where he could see more. And there, a tall monk with a long white beard appeared in front of him. "Your ox is there," he said, and pointed towards the small chapel. Malomytès turned and

12 The story most likely indicates that this is an example of a shared saint; cf. Cuffel (2005). 
wanted to ask who he was and where he came from. The monk vanished. He called again, but didn't see anyone. He made the sign of the cross. Behind the fence, he saw the small chapel of Agios Charalampos and understood that the monk was a divine vision, that he was the saint. Seized by terror and trembling, he kneeled down to pay devotion to the saint. He looked around, feeling only solitude and did not see any bull. Malomytēs, having calmed down, went two steps further down towards the spring to rinse the sweat and cool his mouth. But when he bent over the spring, his eyes fell on the Turkish bandit with his pistol in his hand, right opposite the small chapel. When the Turk met his eyes, he cried out: "come here." Malomytès, frightened, with a dry throat, approached the bandit. "What are you looking for here?" asked the Turk. He told about the animal he had lost. "I have your bull," said the bandit, "come here and I will return it, and pay devotion to the saint that is worshipped by the poor. I tried to kill you three times, when you were on your knees, but every time you vanished in front of my eyes, and I attribute this to your saint. So, take your ox and go back to your village. But come back here and celebrate your saint that saved you."

The next passage describes the founding of the festival and the problems with the Turks at the beginning and again at the end of the nineteenth century (i.e., in 1897, in connection with the Greco-Turkish war). Chatzēgiannē also recounts further miracles, or signs from the saint connected with establishing the celebration. According to another local writer, Christos Paraskeuaïdè (1991: 136) the festival at Tauros goes back to the Turkish period and the miracle Agios Charalampos performed when the farmer from Agia Paraskeuē, Malomytēs, lost his bull. After having searched for his bull for several days, he came to Tauros, where the Turkish bandit had his headquarters near a small chapel dedicated to Agios Charalampos. The rest of the story is the same as told by other sources: the bandit tried to kill Malomytēs three times, but every time the farmer vanished in front of his very eyes, and the Turk ascribed the miracle to the saint. Malomytēs, his friends, and a priest came back to the mountain one Sunday to celebrate a liturgy in the chapel. Since then, the festival has been celebrated annually at the mountain. Alternatively, the following story is told: During the Turkish occupation, a Turk stole a bull. Each time he tried to kill it, a bright light shone in his eyes, until eventually he gave the bull back. This version is related to the belief that the saint is incarnated in a bull (cf. also Aikaterinidès 1979).

According to the legend, the festival dedicated to Ag. Charalampos has been celebrated since the Turkish period, as described in the pamphlet (Chatzēgiannē 1969) that is presented to interested visitors at the office of the organizing committee, the modern version of the ploughmen's guild, whose protector is Ag. Charalampos. Both the date and legend about the Turkish bandit might be seen as a statement in the struggle against the Turks. It has also been suggested (Makistou 1970: 63) that the festival may be traced back to the ancient Greek period but was abandoned early during Turkish rule. This is difficult to prove, however, because 
different rituals that constitute the festival are also found in other places in the northeastern Aegean. Because the festival thus resumes after the appearance of the saint around the beginning of the struggle against the Turks, there is a parallel to other supernatural signs during the same period; for example, finding icons or the appearance of divine persons.

Although the legend about Ag. Charalampos is traced back to the beginning of the nineteenth century, the bibliography about the festival was produced in the twentieth century, and there are many similarities between my own observations and the actual documentation. ${ }^{13}$

\section{COLLECTIVE IDENTITIES}

During the festival dedicated to Agios Charalampos an important ritual is the sacrifice of a bull (Figure 11), which is consumed as a communal meal known as kesketsi. The bull is dedicated by an emigrant. He represents a group of people that always return home to the village during the annual festival of the saint. This is why there is no fixed date for celebrating the festival, just that it is always celebrated around the grain harvest. In 1992 it was postponed until the school terms had finished in South Africa, where a large contingent from the village has settled. In this festival dedicated to a deceased Christian saint, horses and horse races are important elements, particularly for adolescents, and the festival concludes with a large communal meal that the entire village participates in. The various participants at the feast often have entirely different purposes for participating in the festivities. The feast is a popular gathering where all the activities that are performed renew and confirm networks that constitute village solidarity. This is particularly illustrated by the local farmers' union that organizes the festival dedicated to their patron saint. Rather than being an invention of tradition (cf. Hobsbawm \& Ranger 1994), the festival thus becomes a "conservation" of tradition because coming home to the village is coming back home to security and safety, carrying out the same rituals as one's parents and grandparents. The same fact is illustrated in the festival on Tinos because the Vision of Saint Pelagia is a local festival when people from Tinos living in Athens, the U.S., or around the Mediterranean come home for their summer vacations by the end of the threshing month. ${ }^{14}$ The festival expresses the relationship within the human world by emphasizing solidarity and symbolizes the relationship with local "ancestors," as the builders of the church, whose tombs are located on the east side of the main church in the courtyard, and in particular the nun that had the vision. Although this article has not focused on the main festival on Tinos

13 Cf. Håland (2007a, Figures 79, 82, and 85 from 1992), Paraskeuaïdē (1991: 85, Figure 1, and 97, Figure 1 from 1929), Makistou (1970, Figures 64, 67, 69, 71, and 73 from 1969), Aikaterinidēs (1979, plate 1 from 1969 and 1973), Kakouri (1965: 67; she visited the festival in 1964). See also Håland (2007a, chapter 4) for the bibliography of the festival.

${ }_{14}$ The traditional names for June and July, Theristēs 'reaper, harvester' and Alönarēs 'thresher', reflect these activities. 
celebrated on 15 August, it is worth mentioning that 15 August is important concerning the remembrance of specific events for people generally, as illustrated when one of my informants, the aforementioned young Athenian, says: "Some years ago . . . the year I was on Tinos during the Panagia" (i.e., 15 August 1989), thus illustrating the importance of 15 August in general for the Greek people, because the actual dating was given in a quite different context during fieldwork in the Acropolis caves in Athens.

According to the introductory words written in the pamphlet in Agia Paraskeue (Chatzēgiannē 1969), the intention behind founding the farmers' union (i.e., the ploughmen's guild) was to develop the village, and so they were starting a civilizing process by the end of the Turkish period. On the other hand, several of the elements of the festival have a very long tradition within modern and ancient Greek religion and may be traced back to the ancient Greek period, particularly the ceremonial blood sacrifice, the collective banquet, horse races, and divine appearances in periods of crises. These elements are also important features within modern Greek culture in general and very often belong to legends told in connection with religious festivals. As seen in connection with the sanctuary on Tinos and the Acropolis cave, divine appearances in periods of crises in particular are very often the necessary causes for starting the celebration of a festival, such as the commemoration of the miracle performed by Agios Charalampos at Tauros. In the modern era, these appearances are generally linked to the liberation from Turkish rule. Another important feature is the contest (Grk. agon), which is not only demonstrated by the horse races. These factors are important within modern Greek culture; however, their ancient parallels illustrate the traditional importance of the aspects in the geographical area, and their significance for the construction and maintenance of collective identities. ${ }^{15}$

\section{SOME NOTES ON HISTORY, MEMORY, MYTH, AND RE-PRESENTING THE PAST IN THE GREEK CONTEXT}

Ancient myths did not begin as fiction; they originally transmitted real information about real events and observations, sometimes preserving information for millennia within nonliterate societies. People have been literate for so long that they have forgotten how myths encode reality. By accepting the idea that ancient myths are a quite reasonable way to convey important messages orally over many generations, one may restore some of the lost history and teaching about human storytelling such as the Barbers (2004) have convincingly done, by way of recent studies of how the human brain works applied to data from the ancient world.

In earlier scholarship, history was considered synonymous with rapid changes, but now it is realized that stability is no less historical than change and that it is as important

15 That the same factors are used in the construction of collective identities all over the Balkan and Mediterranean areas is another topic that I cannot discuss here, despite its importance; see, however, Håland (2007a, chapter 2). 
to explain stability as change. According to the historian Fernand Braudel, a single society may have different dimensions of time (Braudel 1969: 41-83), and it is particularly la longue durée, connected with his view of the ecological unity of the Mediterranean (Braudel 1990), that is relevant for the material encountered in the Greek context in connection with religious rituals. Because man is prisoner of the climate and the vegetation, it is difficult to escape certain geographical frames and limits of productivity as well as spiritual constraints or mentalities. Therefore, it is important to take account of the history of the infrastructure, the nearly "non-moving history," which everything gravitates around (Braudel 1969: 51-54).

Braudel's la longue durée corresponds to the second and third of Klaus Roth's categories: linear time, cyclical time, and dreamtime or frozen time (cf. Roth 1994: 159-176). The cyclical perception of time is characterized by predictability and repetition, and is typical of peasant societies. Dreamtime or frozen time presupposes a static perception of time without movement and involves an orientation to the past; its vehicle is oral tradition. In Greece, a cyclical perception of time and the perspective of frozen time are still prominent. Even if modern Greece is a country that increasingly depends on tourism, these factors are still important because the farmer mentality does not change easily. For example, this is illustrated by the agricultural calendar, which is also synonymous with the ritual calendar, because the church calendar is added to or built upon the first - that is, the order of nature (cf. Håland 2005, 2007a). In addition, past stages in the development of Greek culture are unusually accessible. The Mediterranean area generally, and Greece particularly, offer a unique opportunity to follow questions of continuity and change over very long spans of time directly and not conjecturally because there is a long literate and archaeological tradition that may be combined with the results of empirical fieldwork.

When carrying out fieldwork on religious festivals in contemporary Greece, one learns that continuity and change, the concept and notion of history, and uses of the past are important in several connections concerning the official versus popular worldview and male versus female; they might interact but also diverge. This has to do with the gendered times and values in Greece.

A festival is very often an excellent occasion to study the relation between the female and male world (i.e. the differences between female and male values), ${ }^{16}$ illustrating the various identities and statuses displayed in the festival. This is illustrated, for example, by the women performing their own liturgy during the Vision festival when singing hymns to Pelagia. A similar ritual is performed during the Dormition festival, although, according to representatives from the official male church, "this is not religion." The ritual continues anyway, and many women prefer joining in here and do not attend the official male liturgy. Thus, when the formal liturgy has finished, many women join in singing hymns to the Panagia in front of the iconostasis (the church icon screen). In fact, many of the female pilgrims, particularly younger ones, do not enter the church until the priests have finished

16 Cf. Håland (2007a). The following is further developed in Håland (2012). 
their liturgy. ${ }^{17}$ Many local women also go to the church carrying chairs and other items with them to spend the night in the church. On the other hand, both men and women tell about dreams and visions in connection with their pilgrimages to Tinos, and the Vision festival is an important part of the entire church. Therefore, I want to emphasize that, as always when trying to classify different parts or categories, the two opposing worlds and valuesystems, the female and male, are nevertheless both complementary and interdependent.

Is the Greek nation's identity a male identity, as opposed to a female, domestic identity? Partly yes, partly no. Yes, because the Greek nation and its identity belong to a male, linear history according to an analysis based on Julia Kristeva and Jill Dubisch's distinction between two kinds of time, female and male time, which I have developed into female and male values. ${ }^{18}$ According to Kristeva men's time is linear time: time as project, teleology, linear and perspective unfolding: time as departure, progression, and arrival, in other words, the time of history. In contrast, women's time is, on the one hand, repetitive (i.e., cyclical) and, on the other hand, beyond time in its ordinary sense. It is eternal (i.e., monumental) time. Kristeva also states that the most recent development of the maternal cult is demonstrated by the body of the Virgin Mother because her body does not die, but moves from one spatiality to another within the same time via Dormition according to the Orthodox faith or via Assumption according to the Catholics. Female time is cyclical and monumental, characterized by repetition and eternity (Kristeva 1986: 191).

On the other hand, there is also a combination of a linear, male history and a cyclical and monumental female history characterized by repetition and eternity because the Panagia announced the resurrection of Greekness to the nun in 1822. Hence, the Panagia is the first and most important saint of the new Greek nation-state. In many ways, she represents Greece, and might be seen as embodying Greece in her eternal aspect. Although embedded in history, the Panagia represents the never-dying spirit of nationhood (unearthed in a field), as contrasted to a specific political entity (the current state of Greece) existing in limited and delimited historical time. The account of finding the icon and building the church also represents women's time because the female miracles and visions are embedded in men's historical time. ${ }^{19}$ The Panagia represents the domestic realm, but she also stands as a national and local political representation beyond the domestic realm. ${ }^{20}$

When conversing with Greek informants, one learns that they do not necessarily always think, or "see," in a "European historical linear" way, but have their own history, which is

17 Many female pilgrims also stay at their hotels or rooms until the official liturgy has finished, such as Dēmetra (who comes on her pilgrimage every year from Peloponnesos), who asked me whether the priests had finished yet, so she could go up (i.e., to the church). Most people say that they go "to the Panagia" (as(because she resides in the icon); that is, not "to the church."

18 Håland (2007a), Kristeva (1986: 187-213), Dubisch (1991: 1-26).

19 This does not mean that history only is represented by linear time. History is also characterized by stability and might also be cyclical, as in agricultural societies; cf. Håland (2007a, chapter 2, 2005) and Braudel (1969: 41-83). See also above.

20 Cf. Dubisch $(1991,1995)$. 
very often local. It might be illustrated by social memory linked to a particular holy place, such as natural landscapes where miracles have occurred and are likely to happen again. It concerns different forms of both conceptions of time and history, as encountered in a Greek society versus northern European researchers (i.e., Eurocentric versus Greek perspectives), which ultimately also affects the interpretation of ancient sources and Europe versus various parts of the world in the current age of globalization.

By presenting the festival and rituals, it is seen that they represent gendered and official versus popular values. When working with Greek cultural history, different conceptions of time and thereby notions of history are encountered. These views are gendered, but they also relate to "us" versus "them," or the Eurocentric linear time versus cyclical time in the Braudelian sense met in Greek peasant society, a time that also is related to religious rituals. This is due to the importance of the Greek agricultural calendar and its annual festivals. One also encounters mythical time (or dreamtime or frozen time), which in the European context is particularly present in the Balkans. The implication of these factors for a Western, Eurocentric analysis of history and ritual are central and important for feminist concerns with escaping the limitations of male-centered temporality, but also when one wants to examine how the Greeks consider their own history because Greek informants do not necessarily have the same historical categories or worldview as a northwestern European, as seen when analyzing the local history of the Greek pilgrimage site on Tinos. During and particularly after the all-night-service (Grk. olonychtia) between 14 and 15 August, many pilgrims are eager to see whether the Panagia will appear at the bell tower (Figure 3); some, particularly

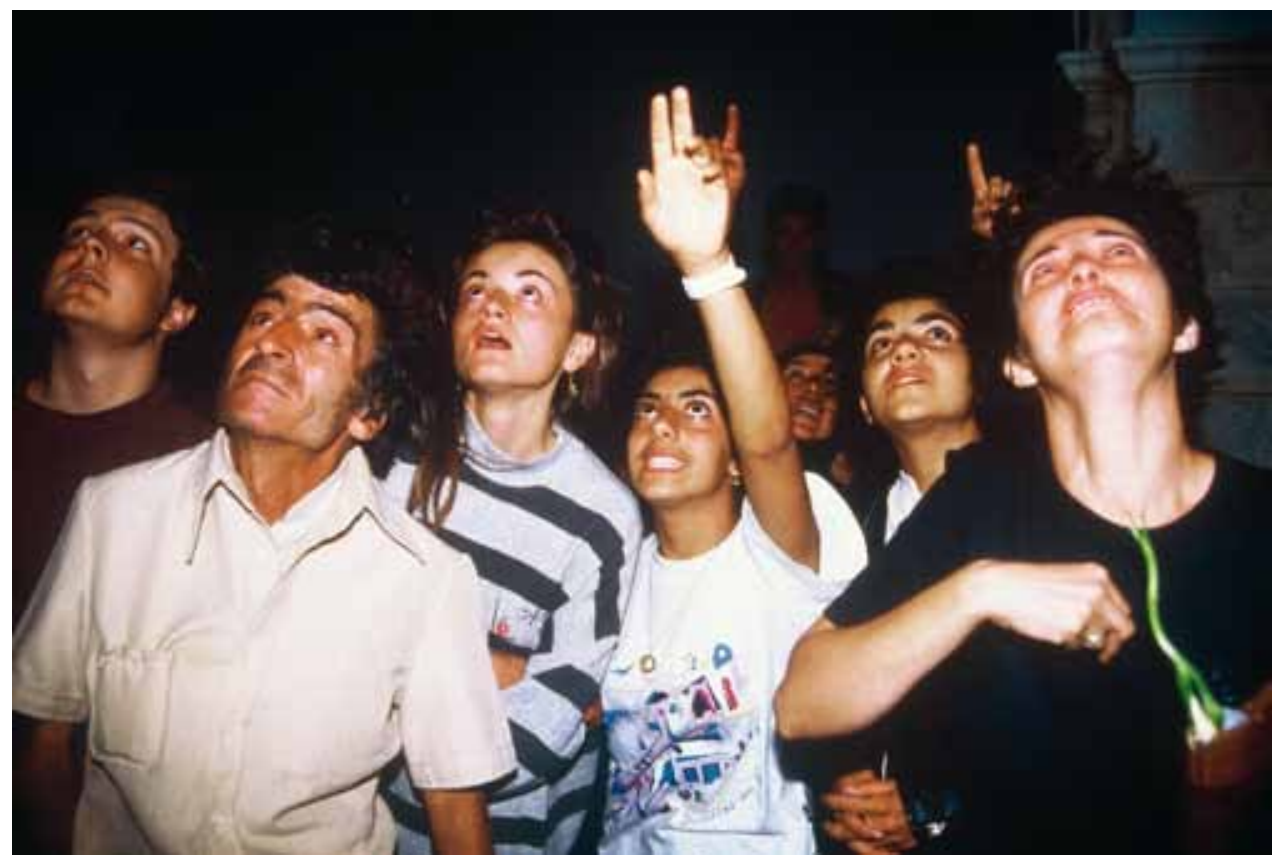

Figure 3. People looking towards the bell tower, 14 August, Tinos. (Photo: E.J. Håland) 
women, also have a vision. Some years ago, for example, a woman outside the church started screaming and exclaiming in fear and happiness simultaneously. At once, inside the church, another woman informed her husband: "She sees the Panagia."

Many of the pilgrims coming to Tinos are fulfilling a vow given after having a dream in which the Panagia has ordered them to go to Tinos, bringing with them particular offerings in exchange for a cure. Before leaving for Tinos, a mother may say: "Save my child, my Panagia, and I will crawl on my knees, all the way to your icon." One of my informants on Tinos, an Athenian women in her fifties, said (in 2007) that her left leg was healed on 7 August 2000 after the Panagia appeared in a dream and demanded that she to go to Tinos and light a candle. Since then, she has gone to Tinos annually during the Dormition. On a later occasion she told me that an additional reason for the annual pilgrimage is that, although she has a degree in mathematics, she was unemployed for a long time, but the Panagia answered her prayers and the annual pilgrimage also became an offering of gratitude after finding a job. Greek history connected with popular religiosity thus becomes beyond time, and a parallel both to the cyclical time related to religious rituals and "frozen" history, whereas Eurocentric history becomes linear. In other words, one sees the consequences of the three notions of history and time encountered in the Greek context illustrating societies that have their own internal logic.

Greek festivals show the interplay or combination of Eurocentric, male, linear history, such as the general description of the Greek revolution of 1821, versus Greek, cyclical, or female time, which has been regarded as history versus myth because women's time often contains miracles and visions, forces generally excluded from official Eurocentric male history, but which nevertheless are important in the Greek context. To Western views of causality and of human nature, it may not be so remarkable that the icon on Tinos should be buried in the ruins of a church, nor that a dry well, once excavated, might be unblocked and begin to flow again. Nor is it odd that in the difficult early days of the Greek War of Independence both priests and populace would be looking for reassurance and hope. On the other hand, this is not the view encountered when talking with people on Tinos, who believe in this as well as the other miracles connected with finding the icon and the subsequent history of the sanctuary, and this has to do with Greece's particular and ambiguous position as both "us" and "them" - that is, its double set of identities, ancient and Byzantine, connected with the "Romeic" or inward-facing and "Hellenic" or outward-facing traditions. (Cf. Herzfeld 1986, 1992; Dubisch 1995; Håland 2007a).In many festivals, for example on Tinos, the festival dedicated to the Dormition of the Panagia is celebrated on 15 August along with Armed Forces Day.

On Armed Forces Day, one encounters a nationalist ideology conforming to Western ideology concerning nation building, while at the same time and in connection with the pilgrimage during the Dormition of the Panagia, one encounters another ideology that represents the "Greek Romeic thesis" (i.e., the inward-facing identity), the Romeic image of Greece, an identity that echoes the Byzantine Empire and hence the Orthodox Christian tradition to which the overwhelming majority of Greeks still adhere. This Romeic (or inside) 
tradition often gains victory over the Hellenic one, and in general the Romeic tradition is protected against Europeans and other Western people. The inward-facing identity is not placed at the disposal of foreigners, as the Greeks do with their common Ancient heritage, which is outward-directed. On Tinos, for example, foreigners may be most interested in the official festival and the elements illustrating nationalism, such as the military escort, the detachment of sailors in the procession, and warships at the harbor, whereas the Greeks are most occupied with carrying out the important rituals such as venerating the icon, which is also passed over them during the procession, and fetching water and earth, rituals connected with deep-seated values, lasting mentalities that have a very long tradition within Greek culture. In fact, the Romeic tradition may have more in common with the ancient world than the Hellenic one, although the Hellenic tradition is better known in Western tradition (see also Håland (2007a, 2007b).

The study of official versus popular religious practices, illustrated by different historical perspectives and conceptions of time, in which dreams and visions are important, has significance because it offers a fuller understanding of religious life in the Mediterranean and indeed of religious culture as a whole than if one only studied official ideological statements. In this way, it is also sees how many parallels there are within the region instead of only focusing on differences.

Certain cultural patterns and social values are found in the same geographical area. There are, of course, many local differences within the Mediterranean area, but the point is that certain cultural patterns, such as the death-cult, recur across the many ethnic, linguistic, and religious groups from Portugal in the west to Iraq in the east. The death-cult is particularly illustrated by the importance of shared saints, such as Agios Charalampos (cf. also Cuffel 2005; Håland 2004). Also important are focal symbols such as icons, water, and earth, and their significance in connection with festivals and life-cycle passages (Håland 2005, 2007a, 2007b). As already stated, icons depicting the Panagia are most venerated among all the Orthodox icons, and her icons are not only important in the Greek context, but also in North Africa, for example, where weeping or sweating icons, particularly the Panagia's, are considered to be important messages for the faithful because the icons may tell the faithful to do various things. I have not come across weeping icons in the Greek context, but the Byzantine specialist Maria Vassilaki (2003) has carried out an interesting comparison between a bleeding icon in the modern Greek context i.e. the Panagia Kardiotissa in Agios Nektarios' Church at Kipoupolis of Peristeri, a suburb northwest of Athens, which was reported in March 2001 to have started bleeding from the neck) and Byzantine sources. The icon of Panagia Kardiotissa was reported to have stopped bleeding on 2 July 2001, and to have cured several people, among others a woman with cancer (Vassilaki 2003: 123). The weeping icons and saints that visit various faithful in their dreams parallel ancient gods and goddesses helping people in fights, such as in the Iliad (20), and also visiting them in dreams or disguised as different persons, such as the relation between Athena, disguised as Mentor (Od. 2.401, 24.548), and her favorite, Odysseus and his son. 
The Greek material therefore has comparative parallels throughout the Mediterranean in both time and space, and my particular study can become part of a larger study.

The importance of the Romeic tradition is not only illustrated when comparing modern, particularly popular, and ancient rituals, but also from a comparative civilizational perspective. As Victor Turner (1991) has illustrated based on examples from Mexico, similar elements are found in the Greek context concerning the ritual process in connection with natural phenomena such as mountains, caves, and springs and one can see how new religions have adapted to older beliefs, often in connection with a native person (Indian or Greek) having a vision in a cave, simultaneous with the beginning of a national struggle for independence. (That is, in official religion one sees a mix of Christianity and the liberation movement adapted to older pre-Christian religions.) In this way, people use old symbols in new political settings just as they also did in the Byzantine period, for example, and most probably also earlier when "adapting" prehistoric "natural" religions to the Olympian pantheon.

\section{REFERENCES}

Aikaterinidēs, Geōrg. N.

1979 Neoellènikes Aimatères Thysies. Leitourgia-Morphologia-Typologia. Athens: Laographia - Deltion tēs Ellēnikēs Laographikēs Etaireias - Parartēma.

Barber, Elisabeth Wayland and Paul T.

2004 Then They Severed Earth from Sky: How the Human Mind Shapes Myth. Princeton and Oxford: Princeton University Press.

Braudel, F.

1969 Écrits sur l'histoire. Paris: Flammarion.

1990 (1949) La Méditerranée et le monde méditerranéen à l'époque de Philippe II. Vols 1-2. Paris: Armand Colin.

Chatzēgiannē, Christopha D.

1969 To panégyri tou taurou: Agias Paraskeuès Lesbou. Mytilēnē.

Clem. Al. Strom.=Clément d'Alexandrie

Les Stromates. Vol. 1, tr. Marcel Gaster and Claude Mondésert 1951. Sources Chrétiennes. Paris: Les Éditions du Cerf.

Cuffel, Alexandra

2005 From Practice to Polemic: shared saints and festivals as 'women's religion' in the medieval Mediterranean. The Bulletin of the School of Oriental and African Studies 68, 3: 401-419.

Danforth, Loring M.

1989 Firewalking and Religious Healing. The Anastenaria of Greece and the American Firewalking Movement. Princeton: Princeton University Press.

Diod.=Diodorus of Sicily

1954 Vol. 6, tr. C. H. Oldfather 1954. The Loeb Classical Library. London: Heinemann.

Dubisch, Jill

1991 Men's Time and Women's Time: History, Myth, and Ritual at a Modern Greek Shrine. Journal of Ritual Studies 5/1: 1-26. 
1995 In a Different Place. Pilgrimage, Gender, and Politics at a Greek Island Shrine. Princeton: Princeton University Press.

Foskolos, E. A.

2004, 1996 (1993, 1968) Perigraphè tès Eureseōs tès Thaumatourgou Agias Eikonas tès Euangelistrias stèn Tèno kata to etos 1823. Skopoi kai drastèriotètes tou Ierou Idrymatos, Tinos. Tinos: Panellēniou Ierou Idrymatos Euangelistrias Tēnou. (Pamphlet distributed by the Church of the Annunciation of Tinos) (English version from 1991, tr. C. Meihanetsidis, the 2004 version, tr. Theodora D. Silvestros).

Hdt. $=$ Herodotus

Vols. 3-4, tr. A. D. Godley 1946, 1950 (1922, 1924). The Loeb Classical Library. Cambridge, MA: Harvard University Press.

Herzfeld, Michael

1986 Ours Once More. Folklore, Ideology, and the making of Modern Greece. New York: Pella.

1992 (1987) Anthropology through the looking-glass. Critical ethnography in the margins of Europe. Cambridge: Cambridge University Press.

Hobsbawm, Eric and Terence Ranger (eds.)

1994 (1983) The Invention of Tradition. Cambridge, New York and Victoria (Australia): Cambridge University Press.

Håland, Evy Johanne

2004 En historisk analyse av sammenhengen mellom gresk dødekult i dag og i antikken (An historical analysis of the relationship between Greek Death Cult, today and in the ancient world). Historisk Tidsskrift 4, 83: 559-591.

2005 Rituals of Magical Rain-Making in Modern and Ancient Greece: A Comparative Approach. Cosmos: The Journal of the Traditional Cosmology Society 17, 2: 197-251.

2007a Greskefester, Moderne og Antikke: En sammenlignende undersøkelse av kvinnelige og mannlige verdier (Greek Festivals, Modern and Ancient: A Comparison of Female and Male

Values). Kristiansand: Norwegian Academic Press. An English version, tr. by Dr Marie Wells, is forthcoming: Newcastle upon Tyne: Cambridge Scholars Publishing.

2007b From Water in Greek Religion, Ancient and Modern, to the Wider Mediterranean and Beyond. Comparative Civilizations Review 56: 56-75.

2008 Les icônes, petit patrimoine religieux grec. In : Fournier, Laurent-Sébastien, ed. Le "Petit Patrimoine" des Européens: Objets et valeurs du quotidien. "Ethnologie de l'Europe". Paris: L’Harmattan: 41-54.

2012 The Dormition of the Virgin Mary, on the island of Tinos: A performance of gendered values in Greece. The Journal of Religious History 36, 1: 89-117.

Il.=Homer, The Iliad

Vol.2, tr. A. T. Murray 1947 (1925). The Loeb Classical Library. Cambridge, Mass.: Harvard University Press.

Kakouri, Katerina, J.

1965 Dionysiaka: Aspects of the popular Thracian Religion of to-day. Athens: G. C. Eleftheroudakis.

Kardamitsēe, Iōannou N.

1992 To monastēri tēs Tènou. Tinos: Ektē.

Karita, Elenē

no date $\bar{E}$ Morphē mias Agias. Ē Pelagia tēs Tēnou. G. Ekdosē, Athens: Ekd. Tēnos.

Kristeva, Julia

1986 Women’s Time. In: Moi, T. (ed.), The Kristeva Reader. Oxford: Basil Blackwell, 187-213.

Makistou, Kōsta

$1970 \bar{E}$ Sellada tēs Agias Paraskeuēs Lesbou. Athens.

Mazarakēs-Ainian, I.

1987 (Prologos), To Epos tou '40. Laikè eikonographia. Athens. 
Od.=Homer

The Odyssey. Vols. 1-2, tr. A. T. Murray 1946 (1919). The Loeb Classical Library. London: Heinemann.

Paraskeuaïē, Christou

1991 É palaia Agia Paraskeué Lesbou. Istorika genealogika kai laographika analekta. Athēna-Agias Paraskeuē Lesbou (or. Mytilēnē 1936).

Roth, Klaus

1994 Time, Folk Culture and Post-Socialist Ethnology in Southeast Europe. In Gustavsson, Anders, ed. Tiden och historien i 1990-talets kulturforskning: Föredrag vid en nordisk forskarkurs i Uppsala. Etnolore 15 (Uppsala: Uppsala universitet: Skrifter från Etnologiska institutionen), 159-176.

Seremetakis, C. Nadia

1991 The Last Word: Women, Death, and Divination in Inner Mani. Chicago: The University of Chicago Press.

Vassilaki, Maria

2003 Bleeding Icons. In Eastmond, Antony and James, Liz (eds.). Icon and Word. The Power of Images in Byzantium. Aldershot and Burlington: Ashgate, 121-133.

Turner, V.

1991 (1969) The Ritual Process. Chicago: Aldine.

Xen.=Xenophon

Vol. 1: Hellenica (Hell.). Vol. 2: Anabasis (An.), tr. Carleton L. Brownson 1947, 1950 (1918, 1921). The Loeb Classical Library. Cambridge, MA.: Harvard University Press.

\section{PRAZNIK, POSVEČEN PRIKAZOVANJU SVETI ( $A G I A)$ ALI BLAŽENI (OSIA) PELAGIJI IN DRUGI RITUALI}

Lokalni festival, namenjen obletnici videnja svete (agia) ali blažene (osia) Pelagije, praznujejo na grškem otoku Tinosu in je posvečen eni najnovejših pravoslavnih svetnic, redovnici Pelagiji, leta 1971 razglašeno za svetnico. Po izbruhu grške osvobodilne vojne (1821) je imela pobožna redovnica Pelagija več mističnih videnj, ki so vodila v odkritje čudežne ikone Oznanjenja. Po izročilu se je Pelagiji v videnjih večkrat prikazala Devica Marija (Panagia), ki ji je naročila, naj začne kopati, da bo našla njeno ikono.

Leta 1823 so ikono izkopali na polju, kjer je ležala okrog 850 let. "Pelagijino Videnje praznujejo vsako leto 23. julija. V času festivala ima poseben pomen izpostavitev njene lobanje ob njeni celici v samostanu Kekhrovouno.

Na podlagi predstavitve tega praznika in nekaterih drugih pomembnejših ritualov iz Grčije, kjer je avtorica raziskovala na terenu, članek obravnava nekatere vidike zgodovine, spomina, mita ali načinov re-prezentacije preteklosti v grškem kontekstu.

Evy Johanne Håland, senior researcher, Marie Curie IntraEuropean Fellow, Department of Archaeology and History of Art, National and Kapodistrian University of Athens, evyhaa@online.no 